\title{
Knowledge of Clean and Healthy Behavior and Quality of Life among School-Children
}

\author{
Gisely Vionalita* and Devi Angeliana Kusumaningtiar \\ Department of Public Health, Faculty of Health Sciences, University of Esa Unggul, Indonesia \\ Jalan Arjuna Utara No.9, Duri Kepa, Kebon Jeruk, Jakarta Barat, DKI Jakarta, 11510 \\ *Corresponding author: gisely@esaunggul.ac.id
}

\begin{abstract}
Background: Quality of life is as one an indicator to profile development of the country as mentioned in sustainability development goals that committed will be achieved in 2019. Quality of children is definitely related to encourage the good habit that can continue practicing in future life. It can be obtained with improvement in knowledge and the clean and healthy behavior. Objective: The objective of this study is to evaluate the relationship between knowledge, the clean and healthy behavior and quality of children in 08 Rawa Buaya Elementary School. This Elementary School is one of public school that located near to flood area mostly defined with poverty environment and lack of hygiene. Method: The study population included 127 people from fourth and fifth grade in that elementary school assumed as the age when the children can answer the questions regarding their life. The data was obtained from face to face interview using structured questionnaire. Data that collected was categorized and analyzed using chi square. Result: The result of this study is there are significant relationship between knowledge and quality of children $(P<0.05)$ and significant relationship between the clean \& healthy behavior and quality of life $(P<0.05)$. Conclusion: This study showed that the importance of being informed how to live in healthy way and practice it in a real life since the beginning of age. It is a lifelong process that can be learnt and make it as a life style and proved as the factors improving the quality of the children. Thus, the encouragement from the parents and teacher are necessary to keep reminding the children to stay clean and healthy.
\end{abstract}

Keywords: quality of life; clean and healthy behavior; elementary school, PHBS, Children

\section{INTRODUCTION}

Reducing poverty and improving human education is part of the Millennium Development Goals (MDGs) agreed upon by countries under the UN (United Nations), one of which is Indonesia. The quality of life is the main effort that can improve the quality of human resources in the future which will relate to the development and the economic of the country. Indonesia has more than $19 \%$ of the population under the age of 10 which means there is still a lot of potential that can be developed to the next generation of quality (Plane, 2017). To make it real, it is important to do some investment in encouraging the quality of life since the age of the children. The quality of the child is the mirror of the nation's quality and the mirror of world civilization.

Good quality in children has a strong relationship with the systematic, sustainability and development of the country. Definition of healthy according to World Health Organization (WHO) is a condition where not only free from disease or weakness, but also balancing between physical function, mental, and social. Thus, the measurement of quality of life related to health includes three function areas namely: physical, psychology (cognitive and emotional), and social (Michalos, 2017). Elementary School is the first stage formal school that teaches the paradigm about clean and healthy life behavior. If it is not planted 
early on, this will disrupt the performance of learning and quality of children in the future. Some habits that can affect children's health behaviors in children, especially in school are the child's breakfast patterns, hand washing habits, ear hygiene, skin hygiene, hygiene, hair hygiene, bathing and also the habits of children to consume unhealthy (Pal and Pal, 2017).

08 Rawa Buaya Elementary School is a school located in flood-prone areas that is still the center of attention of all parties. Settlement of housing and the distance from the river is often being discussed because it is not suitable with the regulation. Heavy population is also a problem of the region. Laying out public facilities such as markets is poorly managed thus create a "muddy" environment, with scattered rubbish that is far from being clean.

School is located in a crowded place that facilitated with many unhealthy food booths around without any permission from the school. This can lead to a reflection of an unhealthy way of life and has been familiarized and taught to the child. Lifestyle like this will be closely related to infectious diseases.

Based on the results of Basic Health Research (Depkes RI, 2008) diarrhea is the leading cause of death in infants (31.4\%) and children under five (25.2\%). Approximately 162,000 children die from diarrhea every year or about 460 toddlers per day. While the results of household health surveys in Indonesia diarrhea is the second leading cause of death in infants, number three for infants, and number five for all ages. Every child in Indonesia has episodes of diarrhea as much as 1.6-2 times per year (Depkes RI, 2011).

08 Rawa Buaya Elementary School itself has complained about the number of children suffering from diarrhea diseases. In fact almost $80 \%$ of children in 4th and 5 th grade of elementary school claimed to have experienced the incidence of Diarrhea (Profile of Rawa Buaya Health Center, 2015). In addition, from the profile of the local Primary Health care in that area also recorded the incidence of worms and leptospirosis is also prone to occur in the flood area like this area. This problem has an impact on the percentage of attendance in primary school, which will affect the effectiveness of the learning process. Attendance is a very important element with the method of learning that is owned by the education system in Indonesia.

The Clean and Healthy Behavior is a manifestation of the reality of human life by applying the principles of the learning process, so that this healthy life behavior will occur because of the learning process that every day they get, both of the school environment, family and community. With this learning process knowledge insight will increase, so that the students are expected to be able to review and interpret something that happens in their life and expected to be able to socialize and practice a healthy way of life.

Based on the problem, the objectives of the study is to obtain the effect of the Knowledge and The Clean and Healthy Behaviour (PHBS) to the Quality of Life of Elementary School Children 08 Rawa Buaya.

\section{METHOD}

This cross-sectional study involved the observation of all members of a population, at one specific point in time. In this case, the study involved all students of 4th and 5th grade as 127 people. The reason for selecting the sample of the group is the students of 4th and 5th grade can describe their own figures, write well, able to be cooperated and not disturbed National Examination execution. Data were analyzed using chi square test to find the relationship between Knowledge and Quality of life also relationship between The Clean and Healthy Behavior (PHBS) and quality of children. Those variables were measured using questionnaires that have been validated and reliable. 


\section{RESULT AND DISCUSSION}

From Table 1, 08 Rawa Buaya Elementary School Children still have the highest proportion in category of poor knowledge. This can be seen from the highest proportion of that category is $78(61.4 \%)$. This shows the low number of knowledge which is important to improve the children's knowledge by updating the health information from the school. According to Notoatmojo (2003) health behavior is influenced by predisposing factors, such as knowledge. From the questionnaires of knowledge it is found that the lowest score was from the question regarding the risk of unhygienic food regarding of the way of processing and the ingredients.

Table 1. Knowledge about behaviour clean and healthy life

\begin{tabular}{lll}
\hline Variable & & Frequency \\
\hline Knowledge & Excellent & $49(38.6 \%)$ \\
\cline { 2 - 3 } & Poor & $78(61.4 \%)$ \\
\hline
\end{tabular}

There was discrepancy found from the score for the question of the importance of washing hands after going to the bathroom. Based on the observations, counseling or health programs conducted in that school was more often prioritizing about handwashing behavior, but rarely discuss about the behavior of consuming unhealthy food. School should also need to improve children's knowledge regarding the important consuming healthy food. Thus it can significantly improve the knowledge of the children.

Based on data obtained, the highest proportion on PHBS in poor category is 65 $(51.2 \%)$ and in excellent category $62(48.8 \%)$. These data indicate that the children in that school still have not practice the clean living habits. Obtained from the score of the questionnaire, the lowest one is for the habit of bringing food from home. This shows a high food demand behavior in the 08 Rawa Buaya elementary school children. This habit is not suitable for clean and healthy living behavior.

Table 2. Behavior clean and healthy life (PHBS)

\begin{tabular}{lll}
\hline Variable & & Frequency \\
\hline PHBS & Excellent & $62(48.8 \%)$ \\
\cline { 2 - 3 } & Poor & $65(51.2 \%)$ \\
\hline
\end{tabular}

Additionally, school itself does not have any control or inspection of food booth that available near to the school environment. This is supported again by the absence of a canteen in the school. From the observation, it is found that food available in food booth near to school are very diverse and usually dominated by food with striking colors that attract children's attention. Prohibitions or provisions for selling are not provided by the school. So, bringing the homemade and healthy food from home is considered as best solution to practice the clean and healthy behavior especially for to keep consuming a healthy food in the future (Larson et al., 2017). The other lowest score was obtained from the low frequency of measuring the weight and height of the child. It is important to control child growth. Child nutrition issues are always becomes concern in child health science at this time. With the observation of growth can avoid obesity and malnutrition (Gibson and Cooke, 2017).

Based on data obtained from all respondents, it was found that the involvement of children in cleaning mosquito larvae in the school environment were low as well. This activity is important to teach children the urgency of maintaining cleanliness and know the factors that cause the emergence of mosquito larvae. This study will certainly familiarize a clean and healthy behavior for the children in the future. So the children will be responsible in behaving in their future life. 
Quality of life (QoL) is a concept that encompasses physical, mental, social, emotional characteristics, which include the complications and effects of a disease therapeutically which depict the individual's ability to play a role in their environment and gain satisfaction from what they did (Verrips et al., 1999). Quality of life in this study was divided into two categories, "excellent" and "poor".

Table 3 Quality of children's' life

\begin{tabular}{lll}
\hline Variable & & Frequency \\
\hline QoL & Excellent & $61(48.1 \%)$ \\
\cline { 2 - 3 } & Poor & $66(51.9 \%)$ \\
\hline
\end{tabular}

The highest proportion was found in the quality of children's' life in "poor" category is $66(51.9 \%)$ and the 'excellent' quality of children's life is $61(48.1 \%)$. From the data obtained the lowest score is in social and physical quality. Social domain shows the ability of children to interact with parents and peers. While the physical quality shows the frequency of abdominal pain, headaches and other illness. Knowing the quality of life of children is considered very important to be able to decide the right approach to the children, thus to create best quality future generation (Dumuid et al., 2017). Difficulties that can be detected by this questionnaire can help in improving the quality of children's' life.

From the data analysis, it was found a significant correlation between the behavior of Clean and Healthy Life with quality of life of children with $\mathrm{P}$ value $0.004(\mathrm{P}<0.05)$.

Table 4 Relationship between knowledge and quality of children's life

\begin{tabular}{llccccc}
\hline \multirow{2}{*}{ Variable } & \multicolumn{2}{c}{ QoL } & Total & Pvalue & OR \\
\cline { 3 - 5 } & & Poor & Excellent & & & \\
\hline Knowledge & Poor & $49(62.8 \%)$ & $29(37.2 \%)$ & $78(100 \%)$ & 0.004 & 2.716 \\
& & & & & \\
& & & & & \\
& Excellent & $17(34.7 \%)$ & $32(65.3 \%)$ & $49(100 \%)$ & & \\
\hline
\end{tabular}

$\mathrm{P}<0.05=$ Significant difference

This data showed that to obtain the good quality of children, they should improve their knowledge regarding the clean and healthy behavior (PHBS). It is found that there was still unexpected answer for the knowledge regarding the risk of unhygienic food. This also supported with the observation result said that there was no health program in terms of the effect of consuming unhealthy food in that elementary school. Furthermore, there is no canteen and also regulation to prohibit children to buy a food outside the school which unhealthy food processing. Children should be reminded and encouraged to bring some food from their own house. It will be healthier for children. This effort can be done by school, because information and regulation like that can improve the children's' knowledge. Knowledge can lead to create good quality of the children.

Based on bivariate analysis, there is a relationship between PHBS and the quality of life of elementary school children N 08 Rawa Buaya with $\mathrm{P}$ value $0.042(\mathrm{P}<0.05)$. This shows to improve the quality of life of children needed a clean and healthy life behavior. Elementary school is a great place to get used to practice PHBS early on. PHBS in schools is a set of behaviors practiced by learners, teachers, and community of the school environment on the basis of awareness as a result of learning, so that independently able to prevent disease, improve health, and play an active role in realizing a healthy environment (DEPKES RI, 2007). 
Table 5 Relationship between behavior clean and healthy life (PHBS) and quality of children's' life

\begin{tabular}{lllllll}
\hline \multirow{2}{*}{ Variable } & \multicolumn{2}{c}{ QoL } & Total & P-value & OR \\
\cline { 3 - 4 } & & Poor & Excellent & & & \\
\hline \multirow{2}{*}{ PHBS } & Poor & $40(61.5 \%)$ & $25(38.5 \%)$ & $65(100 \%)$ & 0.042 & 2.716 \\
\cline { 2 - 5 } & Excellent & $26(41.9 \%)$ & $36(58.1 \%)$ & $62(100 \%)$ & & \\
\hline
\end{tabular}

Providing the facilities for washing hands and encouraging the health counseling by the school will make students and also the teachers aware of the importance of washing hands with running water and using soap. Hand washing with running water and using soap to train the value of discipline character (Watson et al., 2017). Children who are accustomed to good behavior since childhood will bring the behavior into adulthood, and vice versa if children get an education that is not appropriate, will complicate the education of the next stages. Many experts say that the failure of planting a character in a person from an early age, will form a problematic person in his adult future (Lottman, Zawaly \& Niemiec, 2000). Thus, to improve the quality of human in the future, we need to pay attention to health and healthy life habits of school-age children so as to inculcate good habit values and can improve the ability of attention, understand work and adapt academically well in school environment.

\section{CONCLUSION}

Knowledge and the clean and Healthy behavior (PHBS) is an important element to improve and get healthy life habit in the future. Measurement of knowledge and PHBS is done to get information as early as possible on the profile of children in order to improve and develop the ability of children to create a good quality of children.

From the results of this study can be concluded that, there is a relationship between the behavior of clean and healthy living with the quality of life of children. Therefore, it is necessary to increase knowledge and the clean and Healthy behavior (PHBS) for 08 Rawa Buaya Elementary School so that can improve the quality of life of children.

\section{ACKNOWLEGEMENT}

This study was supported by Indonesia Ministry of Higher Education from the "Beginner Lecturer grant" 2016. The authors would like to express their deepest gratitude to children and teachers who participated in this study and the staff at 08 Rawa Buaya Elementary School.

\section{REFERENCES}

Ali, M. (2009). Pendidikan untuk pembangunan nasional: menuju bangsa Indonesia yang mandiri dan berdaya saing tinggi. Grasindo.

Departemen Kesehatan RI (2007). Perilaku hidup bersih dan sehat. Jakarta: Bakti Husada Departemen Kesehatan.

Dumuid, D., Olds, T., Lewis, L. K., Martin-Fernández, J. A., Katzmarzyk, P. T., Barreira, T., ... \& Kuriyan, R. (2017). Health-related quality of life and lifestyle behavior clusters in school-aged children from 12 countries. The Journal of pediatrics, 183, 178-183.

Gibson, E. L., \& Cooke, L. (2017). Understanding Food Fussiness and Its Implications for Food Choice, Health, Weight and Interventions in Young Children: The Impact of Professor Jane Wardle. Current obesity reports, 6(1), 46-56.

Lottman, T. J., Zawaly, S., \& Niemiec, R. (2017). Well-being and well-doing: bringing mindfulness and character strengths to the early childhood classroom and home. 
In Positive Psychology Interventions in Practice (pp. 83-105). Springer International Publishing.

Larson, E. L., Murray, M. T., Cohen, B., Simpser, E., Pavia, M., Jackson, O. \& Saiman, L. (2017). Behavioral Interventions to Reduce Infections in Pediatric Long-term Care Facilities: The Keep It Clean for Kids Trial. Behavioral Medicine, 1-10.

Michalos, A. C. (2017). Social indicators research and health-related quality of life research. In Connecting the Quality of Life Theory to Health, Well-being and Education (pp. 2558). Springer International Publishing.

Notoatmodjo, S, (2007). Kesehatan masyarakat ilmu dan seni. Jakarta: Rineka Cipta.

Pal, J., \& Pal, A. K. (2017). Impact of health education regarding personal hygiene and dietary habits on morbidity profile of students: an intervention study in a government secondary school in a slum area of Kolkata. International Journal Of Community Medicine And Public Health, 4(7), 2492-2497

Plane, D. A. (2017). The sustainability of demographic progress around the world. In Socioeconomic Environmental Policies and Evaluations in Regional Science (pp. 936). Springer Singapore.

Ustama, D. D. (2009). Peranan pendidikan dalam pengentasan kemiskinan. Jurnal Ilmu Administrasi dan Kebijakan Publik, 6(1), 1-12.

Utomo, Budi. (2007). Tantangan Pencapaian Millenium Development Goals (MDGs) Bidang Kesehatan di Indonesia. Jurnal Kesehatan Masyarakat Nasional 1.5

Verrips, E. G. H., Vogels, T. G. C., Koopman, H. M., Theunissen, N. C. M., Kamphuis, R. O. B. P., Fekkes, M., Wit, J. A. N. M. \& Vanhorick, S. P. V. (1999). Measuring healthrelated quality of life in a child population. The European Journal of Public Health, 9(3), 188-193.

Vogels, A. G. C., Verrips, G. H., Koopman, H. M., Theunissen, N. C. M., Fekkes, M. \& Kamphuis, R. P. (2000). TACQOL Manual. Leiden Center for Child Health and Pediatrics LUMC-TNO.

Watson, J. A., Ensink, J. H., Ramos, M., Benelli, P., Holdsworth, E., Dreibelbis, R., \& Cumming, O. (2017). Does targeting children with hygiene promotion messages work? The effect of handwashing promotion targeted at children, on diarrhoea, soil-transmitted helminth infections and behaviour change, in low-and middle-income countries. Tropical medicine \& international health.

Wellman, H. M., Cross, D., \& Watson, J. (2001). Meta-analysis of theory of mind development: The truth about false belief. Child Development, 72, 655-684. 